\title{
Kajian hukum terhadap peraturan daerah Kabupaten Malang yang berkaitan dengan peningkatan penanaman modal
}

\section{Khotbatul Laila}

Khotbatul Laila; Fakultas Hukum Universitas Merdeka; Jl. Terusan Raya Dieng Nomor 62-64; Malang; 65146; Jawa Timur; Indonesia.

ARTICLEINFO

Article history:

Received 2020-02-08

Received in revised form

2020-03-21

Accepted 2020-04-01

Kata kunci:

Peraturan Daerah; Kabupaten

Malang; Penanaman Modal.

\section{Keywords:}

Regional Regulations; Malang

Regency; Investment.

DOI: https://doi.org/10.26905/

idjch.v11i1.4118.

How to cite item:

Laila, K. (2020). Kajian hukum terhadap peraturan daerah Kabupaten Malang yang berkaitan dengan peningkatan penanaman modal. Jurnal Cakrawala Hukum, 11(1), 82-90. doi:10.26905/ idjch.v11i1.4118.

\section{Abstrak}

Salah satu indikator keberhasilan dari upaya meningkatkan pertumbuhan ekonomi dan daya tarik investasi adalah banyaknya kegiatan penanaman modal yang ada. Oleh karena itu sebagai daerah yang bercirikan kota, investasi menjadi suatu hal yang sangat penting bagi pertumbuhan ekonomi di Kabupaten Malang. Kegiatan penanaman modal lebih ditekankan pada upaya pemanfaatan potensi local dan peningkatan kapasitas kelembagaan serta pengembangan berbagai alternatif investasi. Oleh karena itu swasta dan masyarakat perlu terus didorong dan ditingkatkan untuk mengembangkan usaha termasuk menentukan pilihan kegiatan pembangunan. Oleh karenanya, Penelitian dengan judul "Kajian Hukum Terhadap Peraturan Daerah Kabupaten Malang Yang Berkaitan Dengan Peningkatan Penanaman Modal" di Kabupaten Malang menjadi penting sebagai salah satu upaya peneliti untuk ikut serta dalam membantu peningkatan pembangunan di Kabupaten Malang dalam hal perbaikan regulasi dan peraturan daerah.

\footnotetext{
Abstract

One indicator of the success of efforts to increase economic growth and investment attractiveness is the number of investment activities that exist. Therefore, as an area characterized by cities, investment becomes a very important thing for economic growth in Malang Regency. Investment activities are more focused on efforts to utilize local potentials and increase institutional capacity and develop various investment alternatives. Therefore, the private sector and the community need to be encouraged and improved to develop their businesses, including making choices for development activities. Therefore, the research entitled "Legal Review of Malang Regency Regulations Related to Increasing Investment" in Malang Regency is important as one of the efforts of researchers to participate in helping to improve development in Malang Regency in terms of improving regulations and local regulations.
} 


\section{Jurnal Cakrawala Hukum, Volume 11 No. 1 April 2020}

ISSN PRINT 2356-4962 ISSN ONLINE 2598-6538

\section{Pendahuluan}

Undang-undang Nomor 23 Tahun 2014 tentang pemerintahan Daerah memberi peluang kepada daerah berupa kewenangan yang lebih besar untuk mengelola pembangunan secara mandiri dan demokratis. Sebagai daerah otonom, kewenangan yang diberikan berdasarkan azas desentralisasi dalam wujud otonomi yang luas, nyata dan bertanggung jawab, mencakup semua bidang pemerintahan kecuali bidang politik, pertahanan, peradilan, moneter dan agama. Pemberian kewenangan dimaksudkan agar daerah dapat meningkatkan pelayanan dan kesejahteraan masyarakat, mengembangkan demokrasi serta meningkatkan pemerataan pembangunan.

Konsekuensi penerimaan kewenangan yang luas, nyata dan bertanggung jawab serta dalam rangka pelaksanaan undang-undang Nomor 25 Tahun 2007 tentang penanaman modal, maka Badan Penanaman Modal dan Pelayanan Perijinan Terpadu Kabupaten Malang perlu melakukan upaya konkrit menarik investasi agar dapat meningkatkan pertumbuhan ekonomi yang signifikan sebagai upaya peningkatan kesejahteraan masyarakat, meningkatkan pelayanan dan mengembangkan demokrasi serta meningkatkan pemerataan pembangunan.

Upaya yang serius dari pemerintah untuk meningkatkan investasi atau penanaman modal. Setidaknya terdapat tiga fungsi utama birokrasi Pemerintahan secara konseptual yang berlaku umum, yaitu; fungsi pelayanan, fungsi pembangunan dan fungsi pemerintahan umum. Fungsi pelayanan yang berhubungan dengan unit organisasi pemerintahan dan berhubungan langsung dengan masyarakat (public service); fungsi pembangunan yang berhubungan dengan unit oganisasi pemerintahan yang menjalankan salah satu bidang tugas tertentu disektor pembangunan (development function); dan Fungsi pemerintahan umum, berhubungan dengan rangkaian kegiatan organisasi pemerintahan yang menjalankan tugas-tugas pemerintahan umum (regulation and function), termasuk di dalamnya menciptakan dan memelihara ketentraman dan ketertiban.

Upaya untuk menggiatkan penanaman modal di daerah seiring dengan semangat otonomi daerah, pemerintah telah menetapkan beberapa regulasi dalam menunjang pengembangan investasi, diantaranya adalah: Undang-Undang Nomor 1 Tahun 1967 tentang Penanaman Modal Asing dan telah diubah dengan Undang-Undang Nomor 11 Tahun 1970 tentang Perubahan dan Tambahan Undang-Undang Nomor 1 Tahun 1967 tentang Penanaman Modal Asing sebagaimana telah diubah dengan Undang-Undang Nomor 12 Tahun 1970 tentang Perubahan dan Tambahan UndangUndang Nomor 6 Tahun 1968 tentang Penanaman Modal Dalam Negeri dan Undang-Undang Nomor 6 Tahun 1968 tentang Penanaman Modal Dalam Negeri, Undang-Undang Republik Indonesia Nomor 25 Tahun 2007 tentang Penanaman Modal.

Orientasi progam pembangunan ekonomi di Pemerintah Kabupaten Malang berupaya untuk mewujudkan program pembangunan yang sinergis dengan kepentingan pemerintah dan stakeholder termasuk investor dalam rangka mewujudkan pembangunan ekonomi yang berdaya saing. Penanam modal di Kabupaten Malang merupakan bagian yang tidak terpisahkan dengan program pembangunan ekonomi di Kabupaten Malang sebagai upaya untuk meningkatkan pertumbuhan ekonomi, menciptakan lapangan kerja, meningkatkan pembangunan ekonomi berkelanjutan, mendorong pembangunan ekonomi kerakyatan, serta mewujudkan kesejahteraan masyarakat dalam suatu sistem perekonomian yang mapan dan kompetitif.

Berbagai upaya di atas dapat tercapai dalam arti adanya peningkatan penanaman modal di Kabupaten Malang secara optimal, manakala beberapa faktor penunjang tercukupi dan beberapa faktor yang diasumsikan menjadi menghambat iklim penanaman modal dapat dicarikan solusinya 


\section{Kajian hukum terhadap peraturan daerah Kabupaten Malang yang berkaitan dengan peningkatan penanaman modal}

dengan langkah - langkah antara lain: perbaikan koordinasi antar-instansi Pemerintah Kabupaten Malang dengan Pemerintah Pusat, Pemerintah Provinsi, dan dengan Pemerintah Kabupaten/Kota; penciptaan birokrasi yang efesien; kepastian hukum di bidang penanaman modal; biaya ekonomi yang relatif rendah dan berdaya saing tinggi; serta iklim usaha yang kondusif di bidang ketenagakerjaan dan keamanan berusaha. Terkait dengan upaya tersebut, tidak lepas dengan political will pemerintah untuk menentukan program-program yang dapat mendukung pertumbuhan penanaman modal sesuai dengan karakteristik kondisi potensial yang dimiliki oleh Pemerintah Kabupaten Malang.

Selanjutnya untuk memonitor dan mengawasi beberapa keberhasilan program tersebut, pemerintah juga senantiasa melakukan pembinaan. Sebagai upaya untuk melakukan pembinaan, setiap aktivitas yang terkait dengan program pembangunan ekonomi perlu diketahui dan teridentifikasi. Cara untuk menumbuhkembangkan perkekonomian di Kabupaten Malang, pemerintah membuka peluang pada para pembisnis (investor) untuk melakukan investasi di wilayahnya. Setiap pebisnis yang akan menjalankan aktivitas bisnis (perusahaan) di wilayah Kabupaten Malang, diwajibkan untuk mengjukan permohonan perijinan sampai dengan memiliki ijin usaha tetap (IUT).

Sementara ini, baik Pemerintah Provinsi Jawa Timur termasuk Pemerintah Kabupaten Malang sudah berusaha dalam mendorong iklim investasi yang ramah dan sehat. Namun demikian, pada realitasnya ketika regulasi investasi tersebut diimplementasikan masih menuai beberapa persoalan. Diantara persoalan yang dimaksud adalah bahwa regulasi antar pusat dengan daerah, atau daerah provinsi dengan daerah kabupaten/kota di bidang investasi belum adanya sinkronisasi dan tumpang tindih peraturan, sehingga berdampak pada hambatan dan kontra produktif dalam pelaksanaan investasi di wilayah Pemerintah Kabupaten/Kota.

\section{Metode}

Pendekatan yang digunakan ialah pendekatan empiris. Penelitian ini, hukum tidak hanya dikonsepkan sebagai keseluruhan atas asas-asas dan kaidah yang mengatur kehidupan manusia akan tetapi meliputi juga lembaga-lembaga dan proses-proses yang mewujudkan berlakunya kaidah-kaidah itu dalam masyarakat, sebagaimana termanifestasi dan tersimakdalam aksi dan interaksi antar mereka (Soekanto, 2001).

Penulisan ini pendekatan penelitian yang digunakan adalah koseptual approach dengan dasar pertimbangan dengan menggunakan pendekatan konsep dan data empiris yang akan menggali informasi yang semakin padat. Jenis data yang akan digunakan pada penelitian ini adalah Data Primer dan Data Sekunder. Sumber Data: Data Primer dan Data Sekunder.

Teknik pengumpulan bahan hukum yaitu dengan menggunakan tekni penulisan bahan hukum yang kemudian dilanjutkan dengan mengutip langsung atau dengan menggunakan kalimat lain dengan maksud yang sama. Teknik analisis yang digunakan adalah teknik analisis isi (content analysis) dengan inpterpretasi (penulisan dengan jangkauan luas).

\section{Pembahasan}

\subsection{Struktur ekonomi Kabupaten Malang}

Sejak tahun 2010 sampai tahun 2015 secara umum, baik nilai izin prinsip investasi maupun total realisasi investasi di Propinsi Jawa Timur mengalami peningkatan dari tahun ke tahun. Hal ini menunjukkan bahwa iklim usaha di Jawa Timur sangat menjanjikan dan menarik bagi investor.

Dampak sacara langsung dari adanya peningkatan jumlah investasi di Propinsi Jawa Timur ini diikuti dengan penambahan jumlah tenaga kerja yang terserap pada bisnis-bisnis yang berlangsung, hal ini karena dengan adanya investasi yang masuk 


\section{Jurnal Cakrawala Hukum, Volume 11 No. 1 April 2020}

ISSN PRINT 2356-4962 ISSN ONLINE 2598-6538

ke Propinsi Jawa Timur membutuhkan banyak tenaga kerja untuk menjalankan bisnis.

Berdasarkan data perkembangan investasi yang terealisasikan masuk ke Propinsi Jawa Timur dan jumlah tenaga kerja yang terserap di atas dapat diketahui bahwa sejak tahun 2008 sampai dengan 2015 secara umum mengalami kenaikan dari tahun ke tahun, bahkan dari dari 2014 ke tahun 2015 jumlah tenaga kerja yang terserap meningkat secara signifikan. Tenaga kerja yang terserap pada tahun 2014 sebanyak 413.325 orang meningkat sebesar 110,5\% menjadi 870.379 orang pada tahun 2015 .

Kabupaten Malang merupakan wilayah yang cukup diminati di dunia investasi, baik berupa properti maupun penanaman modal. Hal tersebut dibuktikan dengan jumlah perusahaan baik itu lokal maupun asing yang cukup banyak di daerah kabupaten Malang. Jumlah perusahaan di wilayah Kabupaten Malang terus bertambah seiring waktu. Pada tahun 2015, terdapat 20 Perusahaan Penanaman Modal dalam Negeri dan 20 Perusahaan Penanaman Modal Asing. Jumlah tersebut naik dari tahun 2014 yaitu terdapat 19 Perusahaan Penanaman Modal Dalam Negeri dan 19 Perusahaan Perusahaan Penanaman Modal Asing. Hal tersebut menunjukkan bahwa wilayah kabupaten Malang memiliki prospek yang baik di dalam hal investasi, khususnya di bidang penanaman modal. Kondisi tersebut tidak menutup kemungkinan bahwa pada tahun-tahun selanjutnya para investor akan datang dan jumlah perusahaan baru akan muncul di wilayah Kabupaten Malang.

Tenaga kerja memiliki peran penting dalam menunjang kinerja ekonomi daerah. Oleh karena itu pemerintah Daerah memiliki komitmen tinggi dalam pembangungan bidang ketenagakerjaan yang antara lain kinerjanya tercermin dalam Tingkat Partisipasi Angkatan Kerja (TPAK), Tingkat Pengangguran Terbuka (TPT) dan Tingkat Kesempatan Kerja (TKK).

TPAK Kabupaten Malang mencapai 66,04\% pada tahun 2014 yang berarti mengalami penu- runan dbandingkan tahun 2012 yang tercatat $70,26 \%$. Penurunan ini menunjukkan gejala yang kurang baik, oleh karena itu penguatan dibidang ekonomi dan peningkatan kemampan dan keahlian penduduk angkatan kerja sesuai dengan kebutuhan pasar kerja merupakan upaya yang dapat ditempuh pemerintah daerah untuk memacu peningkatan TPAK.

Sektor Investasi berupa Perusahaan Penanaman Modal dalam Negeri maupun Penanaman Modal Asing menyerap tenaga kerja yang jumlahnya cukup banyak. Pada tahun 2015, jumlah tenaga kerja yang terserap dalam Perusahaan Penanaman Modal dalam Negeri maupun Penanaman Modal Asing tercatat sejumlah 26.092. Jumlah tersebut naik dari tahun-tahun sebelumnya. Pada tahun 2013, jumlah tenaga kerja yang terserap dalam sektor ini yaitu sebanyak 24.802, dan pada tahun 2014 jumlah tenaga kerja yang terserap naik lagi menjadi 25.052 tenaga kerja. Hal tersebut menunjukkan bahwa dengan adanya investasi yang berupa Perusahaan Penanaman Modal dalam Negeri maupun Penanaman Modal Asing dapat mempengaruhi berbagai hal mulai dari menciptakan lapangan kerja baru, mengurangi tingkat pengangguran, serta meningkatkan perekonomian baik untuk wilayah Kabupaten Malang itu sendiri maupun nasional.

Peningkatan maupun penurunan nilai investasi dan lapangan kerja di Kabupaten Malang sebenarnya juga dipengaruhi oleh keberdaan dari regulasi-regulasi tingkat nasional dan daerah yang disahkan dan telah diimplementasikan. Secara sederhana investor akan lebih tertarik untuk menanamkan modalnya pada suatu daerah ketika regulasi nasional maupun daerah mendukung dan tidak secara signifikan mengganggu kelancaran investasi.

Begitu halnya dengan perluasan tenaga kerja yang dibangun sebagai efek positif yang timbul ketika investasi telah tertanam disuatu wilayah yang dalam hal ini adalah wilayah pemerintahan nasional dan daerah. Sebelum kita beranjak pada 
peraturan daerah Kabupaten Malang yang berkaitan dengan peningkatan investasi dan perluasan lapangan kerja, berikut ini akan dipaparkan Tiga diantara banyaknya regulasi makro yang berkaitan dengan peningkatan investasi dan perluasan lapangan kerja yang meliputi Undang-Undang Nomor 23 Tahun 2014 tentang Pemerintahan Daerah, Undang-Undang Nomor 25 Tahun 2007 tentang Penanaman Modal, Undang-Undang Nomor 13 Tahun 2013 tentang Ketenagakerjaan.

Data yang telah dihimpun, ada enam peraturan daerah Kabupaten Malang yang berkaitan dengan peningkatan investasi dan perluasan lapangan kerja diantaranya:

1. Perda No. 20 Tahun 2014 tentang Pelimpahan Sebagian Urusan yang Menjadi Wewenang Bupati Di Bidang Pelayanan Administrasi Perizinan Kepada Badan Pelayanan Perizinan Terpadu.

2. Peraturan Daerah Nomor 3 Tahun 2010 tentang Rencana Tata Ruang Wilayah Kabupaten Malang.

3. Peraturan Daerah Kabupaten Malang No. 8 Tahun 2010 tentang Pajak Daerah.

4. Peraturan Daerah tentang RPJMD Kabupaten Malang Tahun 2010-2015.

5. Peraturan Daerah Kabupaten Malang Nomor 10 Tahun 2013 tentang Penyelenggaraan Kepariwisataan.

6. Peraturan Daerah Kabupaten Malang Nomor 1 Tahun 2005 tentang Ketentuan Ketentuan Pokok Pelaksanaan Pemeliharaan Ketentraman dan Ketertiban Umum

Peraturan Daerah No. 20 Tahun 2014 tentang Pelimpahan Sebagian Urusan yang Menjadi Wewenang Bupati di Bidang Pelayanan Administrasi Perizinan Kepada Badan Pelayanan Perizinan Terpadu mengatur mengenai kewenangan pemberian izin investasi berdasarkan tolok ukur urusan masing-masing.
Berdasarkan aspek manfaatnya Peraturan diatas memberikan amanat untuk melayani izinizin yang menjadi izin utama dalam kegiatan investasi dengan mengacu kepada prinsip-prinsip penyederhanaan jumlah perijinan. Konten dari pada disahkannya peraturan ini adalah menawarkan kemudahan dengan menyederhanakan jumlah perijinan. Penyederhanaan jumlah perijinan secara langsung akan mempercepat proses pengurusan administrasi dari investasi itu sendiri. Secara umum peraturan ini tidak bermasalah dan berpotensi positif terhadap iklim investasi pemerintahan daerah karena kadang pengurusan izin yang sangat banyak juga menjadi aspek menurunnya iklim investasi dan ketertarikan investor.

Berdasarkan aspek kesesuaian dengan peraturan diatasnya, perda ini mengacu kepada Undang-Undang No. 32 Tahun 2004 tentang Pemerintah Daerah, Peraturan Pemerintah Nomor 38 Tahun 2007 tentang Pembagian Urusan Pemerintahan antara Pemerintah, Pemerintah Daerah Provinsi dan pemerintah Daerah Kabupaten/Kota. Perda ini juga mengacu kepada keputusan Menteri Pendayagunaan Aparatur Negara No.6 Tahun 2003 tentang Pedoman Umum Pelayanan Publik.

Kecenderungan Perda terhadap investasi dan peningkatan lapangan kerja adalah mendukung peningkatan investasi dalam aspek kemudahan pengurusan perijinan. Cakupan konsentrasi implikasi dari perda yang bersangkutan adalah lebih kearah kemudahan berinvestasi.

\subsection{Peraturan daerah Kabupaten Malang nomor $\mathbf{3}$ tahun 2010 tentang rencana tata ruang wilayah Kabupaten Malang}

Peraturan Daerah Kabupaten Malang No. 3 Tahun 2010 tentang Rencana Tata Ruang Wilayah Kabupaten Malang disahkan untuk mengarahkan pembangunan di Kabupaten Malang dengan memanfaatkan ruang wilayah secara berdaya guna, berhasil guna, serasi, selaras, seimbang dan ber- 


\section{Jurnal Cakrawala Hukum, Volume 11 No. 1 April 2020}

ISSN PRINT 2356-4962 ISSN ONLINE 2598-6538

kelanjutan dalam rangka meningkatkan kesejahteraan masyarakat. Peraturan ini juga membawa amanat pemerintah dalam mewujudkan keterpaduan pembangunan antar sektor, daerah dan masyarakat yang juga sebagai arahan lokasi investasi pembangunan yang dilaksanakan pemerintah, masyarakat dan/atau dunia usaha. Maka keberadaan perda RTRW ini merupakan kejelasan informasi dalam bentuk peta kewilayahan untuk menunjang peningkatan investasi maupun perluasan lapangan kerja.

Berdasarkan aspek kesesuaian dengan peraturan perundang-undangan yang berada diatasnya, perda ini mengacu pada Undang-Undang No. 12 Tahun 1950 tentang Daerah-daerah Kabupaten Lingkungan Provinsi Jawa Timur, UndangUndang Nomor 5 Tahun 1960 tentang Peraturan Dasar Pokok-Pokok Agraria, Undang-undang No. 5 Tahun 1984 tentang perindustrian dan UndangUndang nomor 25 Tahun 2007 tentang Penanaman Modal. Dari beberapa peraturan perundangundangan diatas terlihat bahwa perda ini juga mencoba mengakomodir amanat dari pada peraturan peraturan mengenai penanaman modal dan industri.

Kecenderungan Perda terhadap investasi dan peningkatan lapangan kerja adalah mendukung peningkatan investasi dalam aspek penyampaian informasi mengenai penataan ruang dan wilayah yang telah direncanakan sebagai peluang investasi sebagaimana amanat dalam pasal 3 bagian pertama tentang misi penataan ruang diantaranya adalah mewujudkan kepastian hukum dalam kegiatan usaha sesuai rencana tata ruang serta mendorong peluang investasi produktif.

Secara umum substasi terkait investasi dan lapangan kerja, perda ini menyajikan rencana pengembangan fasilitas kawasan perkotaan di Kabupaten malang semisal pada wilayah pengembangan kepanjen dengan fungsi pengembangan sebagai pusat perdagangan skala daerah, jasa skala daerah dan olahraga skala regional dan nasional.
Selain itu pada wilayah pengembangan Ngantang memiliki fungsi pengembangan sebagai pusat pariwisata malang bagian barat, pusat industri pengolahan dan pemasaran hasil pertanian.

\subsection{Peraturan daerah Kabupaten Malang nomor 8 tahun 2010 tentang pajak daerah}

Peraturan Daerah Kabupaten Malang No. 8 Tahun 2010 tentang Pajak Daerah mengatur mengenai pajak daerah yang perlu untuk dilakukan penyesuaian. Seperti yang kita ketahui sebelumnya pajak daerah yang selanjutnya disebut pajak adalah kontribusi wajib kepada daerah yang terutang oleh orang pribadi atau badan yang bersifat memaksa berdasarkan Undang-Undang, dengan tidak mendapatkan imbalan secara langsung dan digunakan untuk keperluan daerah dan sebesar-besarnya kemakmuran rakyat.

Berdasarkan aspek keseuaian dengan peraturan diatasnya, perda ini mengacu UndangUndang Nomoer 12 Tahun 1950 tentang Pembentukan Daerah-Daerah Kabupaten di Lingkungan Propinsi Jawa Timur, Undang-Undang Nomor 19 Tahun 1997 tentang Penagihan Pajak dengan Surat Paksa, Undang-Undang Nomor 17 Tahun 2003 tentang Keuangan Negara dll. Berdasarkan aspek kesesuaian, perda ini telah mengikuti kaidah dalam pembuatan suatu produk hukum yang legal.

Kecenderungan Perda terhadap investasi dan peningkatan lapangan kerja adalah mendukung adanya investasi dan telah memposisikan produk hukum ini sebagai penjelas kewajiban yang harus ditunaikan setelah proses investasi berlangsung.

Secara umum substasi dari perda ini adalah memberikan penjelas kewajiban yang harus ditunaikan setelah dilakukannya investasi oleh investor yang meliputi pajak hotel, restoran, hiburan, reklame, penerangan jalan, mineral bukan logam dan batuan, parkir, air tanah, sarang burung walet, pajak bumi dan bangunan perdesaan dan 
perkotaan serta bea perolehan hak atas tanah dan bangunan.

\subsection{Peraturan daerah tentang RPJMD Kabupaten Malang tahun 2010-2015}

Peraturan Daerah Kabupaten Malang No. 2 Tahun 2011 tentang Rencana Pembangunan jangka menengah daerah Kabupaten Malang Tahun 20102015 merupakan pedoman atau acuan dalam menetapkan arah kebijakan pembangunan dan strategi pembangunan daerah dalam kurun waktu 5 tahun yang mendatang serta dalam rangka menjamin keberlanjutan pembangunan jangka panjang dan konsistensi antara perencanaan, penganggarann, pelaksanaan dan pengawasan pada setiap tahun anggaran selama 5 tahun yang akan datang sehingga secara bertahap dapat mewujudkan citacita masyarakat Kabupaten Malang.

Berdasarkan aspek kesesuaian Perda ini mengacu pada Undang-undang nomor 25 Tahun 2004 tentang sistem perencanaan Pembangunan Nasional. Kecenderungan perda RPJMD terhadap investasi dan peningkatan lapangan kerja adalah hanya mendukung keamanan ketertiban dan kedamaian sebagai salah satu hal yang sebenarnya juga mendukung kenyamanan investasi. Hal tersebut sebagaimana paparan dari misi Kabupaten Malang 2010-2015 yaitu mewujudkan pemerintahan good governance (tata kelola kepemerintahan yang baik), clean government (pemerintah yang bersih), berkeadilan, dan demokratis, mewujudkan supremasi hukum dan HAM, mewujudkan kondisi lingkungan yang aman, tertib, dan damai, mewujudkan peningkatan ketersediaan dan kualitas infrastruktur, mewujudkan sumber daya manusia yang produktif dan berdaya saing, mewujudkan peningkatan pertumbuhan ekonomi yang berbasis pertanian dan pemberdayaan masyarakat perdesaan, mewujudkan peningkatan kualitas dan fungsi lingkungan hidup, serta pengelolaan sumberdaya alam yang berkelanjutan.
Peraturan Daerah Kabupaten Malang Nomor 10 Tahun 2013 tentang Penyelenggaraan Kepariwisataan mengatur mengenai penyelenggaraan kepariwisataan dalam rangka mendukung perkembangan pariwisata di Kabupaten Malang. Pariwisata saat ini menjadi sektor yang sangat diburu oleh para investor untuk menanamkan modalnya di daerah. Pariwisata menjadi suatu aspek yang hampir memasuki ranah dari kebutuhan manusia. Keberanian Kabupaten Malang dalam mendukung perkembangan pariwisata dalam bentuk perda ini perlu untuk diberikan apresiasi yang cukup tinggi karena hal ini merupakan political will yang belum tentu dilakukan di daerah yang lainnya.

Berdasarkan aspek kesesuaian dengan peraturan diatasnya, perda ini mengacu kepada Undang-Undang Nomor 5 Tahun 1990 tentang Konservasi sumberdaya Alam Hayati dan ekosistemnya, Undang-undang Nomor 13 Tahun 2003 tentang Ketenagakerjaan dan Undang-Undang No.32 Tahun 2004 tentang Pemerintahan Daerah. Berdasarkan aspek kesesuaian dengan peraturan diatasnya perda ini telah menyesuaikan amanat peraturan perundang-undangan dalam perumusan diawalnya, selain itu perda ini juga mengakomodir amanat dari pada peraturan terkait tenaga kerja.

Kecenderungan Perda terhadap investasi dan peningkatan lapangan kerja adalah mendukung peningkatan investasi dalam bentuk industri pariwisata dan juga membuka peluang lapangan pekerjaan yang lebih banyak dalam sektor usaha pariwisata seperti halnya bunyi dari pada tujuan perda ini yaitu mendorong pengembangan sumber daya pada destinasi pariwisata dan memperluas kesempatan berusaha dan lapangan kerja serta meningkatkan peran serta masyarakat dan meningkatkan pendapatan masyarakat begitu halnya dengan pemerintah daerah.

Secara umum substasi terkait investasi dan lapangan kerja, perda ini menyajikan kejelasan informasi dan dukungan pemerintah Kabupaten Malang terhadap penyelenggara pariwisata untuk 


\section{Jurnal Cakrawala Hukum, Volume 11 No. 1 April 2020}

ISSN PRINT 2356-4962 ISSN ONLINE 2598-6538

menyelenggarakan pariwisata di Kabupaten Malang dimana dalam pasal 5 bagian kesatu mengenai penyelenggara pariwisata bahwa badan atau perorangan yang terkait langsung atau tidak dengan industri pariwisata diperbolehkan menyelenggarakan pariwisata di Kabupaten Malang. Pembangunan Pariwisata itu sendiri meliputi industri pariwisata, destinasi pariwisata, pemasaran dan kelembagaan kepariwisataan.

Kelemahan perda ini adalah tidak mengatur secara teknis prosedur pengurusan pendaftaran penyelenggaraan usaha pariwisata. Hal ini penting sebagai informasi penjelas bagi badan usaha ataupun perorangan yang ingin ikut serta dalam menyelenggarakan usaha pariwisata di Kabupaten Malang.

\section{Simpulan}

Berdasarkan pembahasan tersebut diatas, maka dapat disimpulkan bahwa Implikasi Hukum dari adanya ketidak jelasan (kekaburan Norma) Terkait penyelesaian sengketa Perbankan Syariah dalam Pasal 55 ayat (2) Undang-Undang Perbankan Syariah Pasca Putusan Mahkamah Konstitusi Nomor 93/PUU-X/2012 adalah menyebabkan adanya ketidak kepastian hukum bagi para pihak yang akan menyelesaikan sengketa perbankan syariah melalui jalur non-litigasi.

\section{Daftar pustaka}

Abdul Wahab, Sholichin. 1991. Pengantar Analisis Kebijakan Negara. Jakarta. Rineka Cipta.

2004. Analisis Kebijakan Publik dari Formulasi ke Implementasi. Jakarta. Rineka Cipta.

Arikunto, Suharsimi. 1986. Prosedur Penelitian Suatu Pendekatan Empirik. Jakarta. PT. Bina Aksara.

1990. Manajemen penelitian, Jakarta. Rineka Cipta.

Badan Pusat Statistik. 2015. Kabupaten Malang dalam Angka.
Faisal, Sanapiah, 1990, Pendekatan Kualitatif Dasar-dasar dan Aplikasinya, Malang. Yayasan Asih Asah Asuh.

Den Berght, Vren. 1980. Metode dan Tehnik Penelitian Masyarakat. Jakarta. Gramedia.

Bakri, Masykuri. 2002. Metode Penelitian Kualitatif: Tinjauan Teoritis dan Praktis. Malang. Lembaga Penelitian UNISMA dan Visipres.

Bogdan,Robert dan Steven J. Taylor. 1992. Pengantar Metode Penelitian Kualitatif. Surabaya. Usaha Nasional.

Bungin, Burhan (ed.). 2001. Metodologi Penelitian Kualitatif. Jakarta. Rajagrafindo.

Dunn, William N. 1996. Pengantar Analisis Kebijakan Publik (terjemahan) Yogjakarta. Gadjah Mada University Press.

2000. Pengantar Analisis Kebijakan Publik (terjemahan). Yogjakarta. Gadjah Mada University Press.

2003. Pengantar Analisis Kebijakan Publik (terjemahan). Yogjakarta. Gadjah Mada University Press.

Dye, Thomas R. 1972. Understanding Public Policy. New Jersey. Prentice-Hall International, Engewood Cliffs.

Feryna, Y. (2016). Makna kesepakatan para pihak terhadap perubahan modal dasar perseroan terbatas. Jurnal Cakrawala Hukum, 7(2), 257-267. doi:10.26905/idjch.v7i2.1916.

Fletcher, J.R., R.G. Gibb. 1992. Land Resource Survey Kandbook for Soil Conservation Planning in Indonesia. Alih Bahasa.

Hadi, Sutrisno. 1994. Metodologi Research Jilid I. Yogjakarta. Andi Offset.

Jones, Charles 0. 1977. An Introduction to The Study of Public Policy. Morth Seituate, Duxbury, Press. (terjemahan). PT Raja, Grafindo Persada. Jakarta.

Miles, Matthew B., dan A. Michael Huberman. 1994. Qualitative Data Analysis: An Expanded Sourcebook. London: sage. 
Mintzberg, H. 1979. The Structuring of Organizations, Prestice-Hall, Englewood cliffs, NJ.

Moleong, Lexy J. 2004 Metodologi Penelitian Kualitatif. Bandung. Remaja Rosda Karya.

Raytiaputri, R. (2016). Perkecualian terhadap prinsip larangan pembatasan kuota impor terkait penanaman modal di Indonesia. Jurnal Cakrawala Hukum, 7(1), 98-111. doi:10.26905/idjch.v7i1.1785.

Suhartono, Agus. 2010. dalam acara International Conference on Indonesian Studies (ICSSIS) 2010, tanggal 9 Agustus 2010 di Fakultas Ilmu Pengetahuan Budaya Universitas Indonesia.
Sunarko. 2000. Public Policy Pengertian Pokok untuk Memahami dan Menganalisa Kebijaksanaan Pemerintah. Surabaya. Airlangga University Press.

Subarsono, AG. 2005. Analisis Kebijakan Publik, Konsep Teori dan Aplikasi. Yogjakarta. Pustaka Pelajar.

White, Jay D. \& Guy B. Adams. 1994. Research in Public Administration, London. Sage Publications.

Zazili, A., Fathoni, F., \& Firmansyah, A. (2016). Pemberian insentif penanaman modal sebagai upaya daya tarik investasi di daerah. Jurnal Cakrawala Hukum, 7(1), 112-122. doi:10.26905/idjch.v7i1.1786. 